\title{
LETTER
}

\section{Glucocorticoids in sepsis: dissecting facts from fiction}

\author{
Charles L Sprung*1, Djillali Annane², Mervyn Singer ${ }^{3}$, Rui Moreno ${ }^{4}$ and Didier Keh ${ }^{5}$; for the CORTICUS Study Group \\ See related commentary by Marik, http://ccforum.com/content/15/3/158
}

Dr Marik's recent commentary [1] states that "..as a result of an overwhelming selection bias, only approximately $5 \%$ of eligible patients were enrolled in the CORTICUS study [2]." As its authors, we are unaware as to what constitutes this overwhelming bias and from where he has plucked a figure of $5 \%$. CORTICUS enrolled patients with clinical evidence of infection, systemic inflammatory response syndrome, shock within 72 hours (defined by a systolic blood pressure $<90 \mathrm{mmHg}$ despite adequate fluid replacement OR need for vasopressors for $\geq 1$ hour), and hypoperfusion or organ dysfunction attributable to sepsis [2]. The placebo group received a maximum norepinephrine dose of $0.4 \pm 0.5 \mathrm{mcg} / \mathrm{kg} /$ minute and their 28 -day mortality was $31.5 \%$. We openly acknowledged that slow recruitment was partly related to loss of equipoise; however, the above data not only appear representative of real life practice but are comparable to other contemporary septic shock studies, for example, VASST [3]. His contention that 7 to 10 days of low-dose hydrocortisone should be considered in patients receiving norepinephrine or equivalent at doses $>0.1 \mathrm{mcg} / \mathrm{kg} /$ minute within 12 hours of shock onset is not supported by any evidence base, contradicts presently accepted international recommendations [4] and portrays a far more striking example of bias.

Competing interests

The authors declare that they have no competing interests.

\section{Author details}

'Hadassah Hebrew University Medical Center, Jerusalem, 91120 Israel. 2Raymond Poincaré Hospital (Assistance Publique-Hôpitaux de Paris), Garches, CP 92380 France. ${ }^{3}$ University College London, London, WC1E 6BT, United Kingdom. ${ }^{4}$ UCIP, Hospital de St António dis Capuchos, Centro Hospitalar de Lisboa Central, E.P.E., 1169-050 Lisbon, Portugal. . ${ }^{5}$ Charité, Universitaetsmedizin, Berlin, 13353 Germany.

Published: 13 October 2011

\section{References}

1. Marik PE: Glucocorticoids in sepsis: dissecting facts from fiction. Crit Care 2011, 15:158.

2. Sprung CL, Annane D, Keh D, Moreno R, Singer M, Freivogel K, Weiss YG, Benbenishty J, Kalenka A, Forst H, Laterre PF, Reinhart K, Cuthbertson BH, Payen D, Briegel J: Hydrocortisone therapy for patients with septic shock. NEngl J Med 2008, 358:111-124.

3. Russell JA, Walley KR, Singer J, Gordon AC, Hebert PC, Cooper J, Holmes CL, Mehta S, Granton JT, Storms MM, Cook DJ, Presneill JJ, Ayers D, for the VASST Investigators: Vasopressin versus norepinephrine infusion in patients with septic shock. N Engl J Med 2008, 358:877-887.

4. Dellinger RP, Levy MM, Carlet JM, Bion J, Parker MM, Jaeschke R, Reinhart K, Angus DC, Brun-Buisson C, Beale R, Calandra T, Dhainaut JF, Gerlach H, Harvey M, Marini JJ, Marshall J, Ranieri M, Ramsay G, Sevransky J, Thompson BT, Townsend S, Vender JS, Zimmerman JL, Vincent JL; International Surviving Sepsis Campaign Guidelines Committee; American Association of CriticalCare Nurses; American College of Chest Physicians; American College of Emergency Physicians; Canadian Critical Care Society; European Society of Clinical Microbiology and Infectious Diseases; et al:. Surviving Sepsis Campaign: International guidelines for the management of severe sepsis and septic shock: 2008. Crit Care Med 2008, 36:296-327.

*Correspondence: charles.sprung@ekmd.huji.ac.il

${ }^{1}$ Hadassah Hebrew University Medical Center, Jerusalem, 91120 Israel

Full list of author information is available at the end of the article 